Atmos. Chem. Phys., 19, 13053-13066, 2019

https://doi.org/10.5194/acp-19-13053-2019

(C) Author(s) 2019. This work is distributed under

the Creative Commons Attribution 4.0 License.

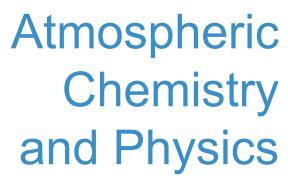

(c) (P)

\title{
Chemical composition of ultrafine aerosol particles in central Amazonia during the wet season
}

\author{
Hayley S. Glicker ${ }^{1}$, Michael J. Lawler ${ }^{1}$, John Ortega ${ }^{1}$, Suzane S. de Sá ${ }^{2}$, Scot T. Martin ${ }^{2,3}$, Paulo Artaxo ${ }^{4}$, \\ Oscar Vega Bustillos ${ }^{5}$, Rodrigo de Souza ${ }^{6}$, Julio Tota ${ }^{7}$, Annmarie Carlton ${ }^{1}$, and James N. Smith ${ }^{1}$ \\ ${ }^{1}$ Department of Chemistry, University of California, Irvine, Irvine, California 92697, USA \\ ${ }^{2}$ School of Engineering and Applied Sciences, Harvard University, Cambridge, Massachusetts 02138, USA \\ ${ }^{3}$ Department of Earth and Planetary Sciences, Harvard University, Cambridge, Massachusetts 02138, USA \\ ${ }^{4}$ Institute of Physics, University of São Paulo, Rua do Matão 1371, 05508-090, São Paulo, SP, Brazil \\ ${ }^{5}$ Chemistry and Environment Center, Instituto de Pesquisas Energéticas e Nucleares, 05508-000, São Paulo, SP, Brazil \\ ${ }^{6}$ Meteorology Department, Universidade do Estado do Amazonas, 69050-020, Manaus, AM, Brazil \\ ${ }^{7}$ Institute of Engineering and Geoscience, Universidade Federal do Oeste do Pará, 68035-110, Santarém, PA, Brazil
}

Correspondence: James N. Smith (jimsmith@uci.edu)

Received: 28 March 2019 - Discussion started: 24 April 2019

Revised: 3 September 2019 - Accepted: 9 September 2019 - Published: 23 October 2019

\begin{abstract}
Central Amazonia serves as an ideal location to study atmospheric particle formation, since it often represents nearly natural, pre-industrial conditions but can also experience periods of anthropogenic influence due to the presence of emissions from large metropolitan areas like Manaus, Brazil. Ultrafine (sub-100 nm diameter) particles are often observed in this region, although new particle formation events seldom occur near the ground despite being readily observed in other forested regions with similar emissions of volatile organic compounds (VOCs). This study focuses on identifying the chemical composition of ultrafine particles as a means of determining the chemical species and mechanisms that may be responsible for new particle formation and growth in the region. These measurements were performed during the wet season as part of the Observations and Modeling of the Green Ocean Amazon (GoAmazon2014/5) field campaign at a site located $70 \mathrm{~km}$ southwest of Manaus. A thermal desorption chemical ionization mass spectrometer (TDCIMS) characterized the most abundant compounds detected in ultrafine particles. Two time periods representing distinct influences on aerosol composition, which we label as "anthropogenic" and "background" periods, were studied as part of a larger $10 \mathrm{~d}$ period of analysis. Higher particle number concentrations were measured during the anthropogenic period, and modeled back-trajectory frequencies indicate transport of emissions from the Manaus
\end{abstract}

metropolitan area. During the background period there were much lower number concentrations, and back-trajectory frequencies showed that air masses arrived at the site predominantly from the forested regions to the north and northeast. TDCIMS-measured constituents also show distinct differences between the two observational periods. Although bisulfate was detected in particles throughout the $10 \mathrm{~d}$ period, the anthropogenic period had higher levels of particulate bisulfate overall. Ammonium and trimethyl ammonium were positively correlated with bisulfate. The background period had distinct diurnal patterns of particulate cyanate and acetate, while oxalate remained relatively constant during the $10 \mathrm{~d}$ period. 3-Methylfuran, a thermal decomposition product of a particulate-phase isoprene epoxydiol (IEPOX), was the dominant species measured in the positive-ion mode. Principal component analysis (PCA) was performed on the TDCIMS-measured ion abundance and aerosol mass spectrometer (AMS) mass concentration data. Two different hierarchical clusters representing unique influences arise: one comprising ultrafine particulate acetate, hydrogen oxalate, cyanate, trimethyl ammonium and 3-methylfuran and another made up of ultrafine particulate bisulfate, chloride, ammonium and potassium. A third cluster separated AMSmeasured species from the two TDCIMS-derived clusters, indicating different sources or processes in ultrafine aerosol 
particle formation compared to larger submicron-sized particles.

\section{Introduction}

Atmospheric aerosols are ubiquitous in the troposphere, and organics contribute a large fraction to their chemical composition (Jimenez et al., 2009). Models continue to have difficulty estimating the organic contribution to aerosols in regions with both biogenic and anthropogenic influence (Shrivastava et al., 2017). Anthropogenic emissions have increased with global population, and the resulting influences of such emissions on secondary organic aerosol (SOA) formation continue to be assessed (Hofmann, 2015). The reactive chemistry of organics in the presence of different regulating species from urban sources, like sulfur dioxide $\left(\mathrm{SO}_{2}\right)$ and oxides of nitrogen, remains uncertain (Shrivastava et al., 2017), although recent efforts have successfully incorporated this chemistry into air quality models simulated for the southeastern United States (Carlton et al., 2018). Models are unable to predict the relationships between particle physicochemical properties and cloud formation and precipitation (IPCC, 2013). Reducing this uncertainty requires an understanding of the mechanisms by which particles form and grow in the atmosphere, which mostly determine the potential of these particles to serve as cloud condensation nuclei $(\mathrm{CCN})$.

The Amazon Basin is an ideal location to study how biogenic emissions, anthropogenic trace gases and oxidants, and biomass burning impact the number and composition of atmospheric aerosol particles. The Amazon Basin is one of the few remaining tropical regions on Earth in which near-natural conditions, free of direct anthropogenic influence, can be found. It has been referred to as the "Green Ocean", since particle concentrations can be as low as those seen over the ocean, and, like the marine atmosphere, small changes in particle properties can have a major impact on clouds and climate (Andreae et al., 2004). While isoprene is the most abundantly emitted biogenic volatile organic compound (BVOC), monoterpenes and sesquiterpenes are observed in amounts potentially sufficient for influencing particle composition (Alves et al., 2016; Jardine et al., 2011, 2015; Yáñez-Serrano et al., 2015; Yee et al., 2018). While on an annual basis, aerosol particle sources in the Amazon Basin are dominated by the oxidation of BVOCs by $\mathrm{OH}$ and $\mathrm{O}_{3}$, in many parts of the Amazon, anthropogenic emissions of trace gases and oxidants, as well as human-caused biomass burning, can have a significant impact on shorter timescales (Martin et al., 2010; de Sá et al., 2017, 2019). Biomass-burning events, both for land clearing as well as pasture and cropland maintenance, can produce particles at high number and mass concentrations. Increased urbanization in the Amazon, for example in the city of Manaus, Brazil, with a 2017 pop- ulation of 2.1 million, represents a large emission source of both gases and particles and has led to increased regional transportation infrastructure and resulting increases in oxides of nitrogen $\left(\mathrm{NO}_{x}\right.$; IBGE, 2017). The latter will have important implications on the reactive pathways of BVOCs and the formation of SOA (de Sá et al., 2018). With the opportunity to observe aerosol particles under pristine conditions, combined with the presence of growing urban centers and increased land use change that represent significant regional sources of oxidants and other key trace gases, this region presents opportunities for understanding both past and future drivers of atmospheric chemistry and climate.

Aerosol properties in the Amazon Basin show a seasonal dependence, reflecting seasonal variability in emissions and deposition. During the wet season (December through March), the region is dominated by natural emissions, as accumulation-mode (particle diameters between 0.1 and $2.5 \mu \mathrm{m}$ ) and coarse-mode (diameters above $2.5 \mu \mathrm{m}$ ) particles tend to be lower in concentration due to wet deposition (Andreae, 2009). In the wet season, ambient particle number concentrations often represent pristine, near-natural concentrations and are in the range of $300-600 \mathrm{~cm}^{-3}$ (Zhou et al., 2002). Previous measurements of particle number-size distributions in Amazonia during the wet season show that ultrafine particles are present intermittently, most likely linked to times of local pollution events, while both Aitken and the accumulation mode are continuously present (Zhou et al., 2002). While the wet season episodically experiences high particle number concentrations, the dry season (June through September) experiences higher number concentrations most of the time, which can alter cloud microphysics, radiative effects and the hydrological cycle (Andreae et al., 2002, 2004; Rcia et al., 2000). While it was previously thought that particle composition during the dry period is dominated by biomass burning, recent measurements of submicron particle $\left(\mathrm{PM}_{1}\right)$ composition show a larger influence from BVOCs due to decreased wet deposition, resulting in positive feedbacks on oxidants and emissions (de Sá et al., 2019). Seasonal variations in isoprene, sesquiterpenes and monoterpenes have been measured, with higher mixing ratios in the dry season (Alves et al., 2016). Additionally, with the lack of rainfall, in-basin pollution may be more prevalent, especially in areas downwind of cities and settlements (Martin et al., 2010).

Unlike in other forested regions, particles with a diameter smaller than $30 \mathrm{~nm}$ are rarely observed over the Amazon Basin, suggesting that new particle formation events seldom occur near the ground (Martin et al., 2010). In other regions, new particle formation has been seen to occur during the daytime under sunny conditions, suggesting that both boundary layer dynamics and photochemistry are important factors (Bzdek et al., 2011). Varanda Rizzo et al. (2018) recently analyzed 4 years of particle size distributions acquired at the TT34 tower site located $60 \mathrm{~km}$ northwest of Manaus. Regional new particle formation and growth events were detected in only $3 \%$ of total days observed, whereas bursts of 
ultrafine particles that lasted as least an hour occurred on $28 \%$ of the days. Those "burst events" were equally likely to occur during the daytime as during the night, and the authors hypothesized that daytime events were caused by interrupted photochemical new particle formation, whereas nocturnal events might be due to emissions and/or fragmentation of primary biological particles. Recent airborne observations in the Amazon suggest that particle nucleation and growth can be initiated in the upper troposphere, with upwelling air masses transporting reactants into the free troposphere and downwelling air masses transporting aerosol particles and condensable compounds back into the boundary layer, where particles can continue to grow via condensation and coagulation (Andreae et al., 2018; Fan et al., 2018; Wang et al., 2016). Once formed, ultrafine particles can be key participants in a variety of atmospheric processes. One example of this is the subject of a recent study by Fan et al. (2018), who have suggested that ultrafine particles can increase the convective intensity of deep convective clouds. High concentrations of ultrafine particles, when present with high water vapor concentrations that are typical in the Amazon atmosphere, can form high concentrations of small cloud droplets that release latent heat and thereby result in more powerful updraft velocities.

While recent research provides some clarity on the origin, transport and climate impacts of ultrafine particles in the Amazon, very little is known about the chemical composition of these particles. Globally, measurements show that a major component of atmospheric ultrafine aerosol is organic compounds produced from BVOC oxidation (Bzdek et al., 2011; Riipinen et al., 2012; Smith et al., 2008). Many of these direct measurements of the composition of atmospheric ultrafine particles have been performed using the thermal desorption chemical ionization mass spectrometer (TDCIMS; Voisin et al., 2003). For example, TDCIMS measurements performed outside of Mexico City attribute about $90 \%$ of the growth of freshly nucleated particles to oxidized organics (Smith et al., 2008). In the boreal forest of Finland, the contribution of oxidized organics is close to $100 \%$, and an analysis of composition suggests that marine emissions can play an important role in that process (Lawler et al., 2018). For the smallest particles measurable by TDCIMS, with diameters from 8 to $10 \mathrm{~nm}$, between $23 \%$ and $47 \%$ of the constituents may be derived from organic salt formation, a reactive uptake mechanism that requires the presence of strong bases such as gasphase amines (Smith et al., 2010).

Similar to other parts of the world, particles in the Amazon Basin are typically composed of $70 \%-80 \%$ organics by mass in both the fine and coarse size ranges (Graham et al., 2003). The composition of ultrafine particles has not been directly measured, although one study has proposed that the major component could be oxidized organics that have condensed onto potassium salt-rich primary particles emitted from active biota (Pöhlker et al., 2012). An understanding of the origin and chemical composition of ultrafine particles in the Amazon gives insight into their formation and growth processes. To improve on modeling the coupling of chemistry and climate in this sensitive region, incorporating accurate representations of particle formation and growth processes is required.

The most recent, and currently the largest, field campaign for studying the Amazon atmospheric chemistry and cloud processes was the Observations and Modeling of the Green Ocean Amazon (GoAmazon2014/5) experiment, which took place outside of Manaus from 1 January 2014 to 31 December 2015 (Martin et al., 2016). Two intensive observational periods (IOPs) were carried out during GoAmazon2014/5, corresponding to wet and dry seasons in 2014. This paper explores the chemical composition of ultrafine particles observed by TDCIMS during IOP1, which took place from 1 February to 31 March 2014. Specifically, we focus on 10 consecutive days that experienced air masses from both remote, primarily forested regions and the large metropolitan region of Manaus. This study investigates the influence of anthropogenic and biogenic emissions on the chemical composition of ultrafine particles in this region, from which one can infer the chemical processes that led to the formation and growth of ambient ultrafine particles in this region. The time evolution of select compounds in ambient ultrafine particles is analyzed, and compared to AMS measurements, using principal component analysis (PCA) in order to gain additional insights into the contribution of various emission sources to ultrafine-particle composition.

\section{Methodology}

\subsection{T3 site description}

All data presented were collected at the $\mathrm{T} 3$ site $\left(3.2133^{\circ} \mathrm{S}\right.$, $\left.60.5987^{\circ} \mathrm{W}\right)$, located $70 \mathrm{~km}$ west of Manaus, Brazil, during the GoAmazon2014/5 campaign (Martin et al., 2016). The T3 site is located within pasture land located $10 \mathrm{~km}$ northeast of Manacapuru, Brazil. The site included the Atmospheric Radiation Measurement (ARM) Mobile Facility no. 1 (AMF1), the ARM Mobile Aerosol Observing System (MAOS), and four modified shipping container laboratories containing instruments deployed by universities and other research organizations.

\subsection{Thermal desorption chemical ionization mass spectrometry}

Ambient ultrafine-particle composition was characterized using TDCIMS. TDCIMS is an instrument designed specifically for the measurement of the molecular composition of size-resolved ultrafine aerosol particles (Smith et al., 2004; Voisin et al., 2003). In brief, sampled atmospheric particles are charged by a unipolar charger and are collected via electrostatic deposition on a platinum $(\mathrm{Pt})$ filament over varying collection times. During this campaign, collection times were 
either for $1 \mathrm{~h}$ or $30 \mathrm{~min}$, depending on the anticipated sample mass. A typical sample mass collected on the filament ranged from 10 to $100 \mathrm{ng}$. After collection, the filament was moved into an atmospheric pressure chemical ionization source region and resistively heated to desorb the particulate-phase components. These desorbed components were chemically ionized and detected using a quadrupole mass spectrometer (Extrel Corp.). A zero-air generator (Parker Hannifin, model HPZA-3500) provided the source of reagent ions $\left(\mathrm{H}_{2} \mathrm{O}\right)_{n} \mathrm{H}^{+}$ and $\left(\mathrm{H}_{2} \mathrm{O}\right)_{n} \mathrm{O}_{2}^{-}(n=1-3)$; TDCIMS operation with these ion chemistries is referred to as either the positive- or negativeion mode, respectively. Complete mass spectra of desorbed compounds were obtained at the beginning of IOP1 (Fig. S1 in the Supplement) to determine ions with the highest ion abundances. These ions were then measured for the duration of the campaign by operating the quadrupole mass spectrometer in "selected-ion mode", in which the quadrupole mass spectrometer rapidly switched among approximately 12 ions to optimize sensitivity with high temporal resolution.

Both positive- and negative-ion-mode chemical analyses were performed during the two IOPs and are publicly available on the campaign data archive (Smith, 2016). During IOP1, several days of measurements were impacted by intermittent power outages and brownouts. IOP2 was characterized by comparatively lower concentrations of ultrafine particles, which is consistent with prior observations (Martin et al., 2010; Varanda Rizzo et al., 2018). Because of this, we focus our analysis on 10 consecutive days during IOP1 when instruments were operating consistently. This period also happened to coincide with the arrival of two distinct and consecutive air masses, which allows for more accurate sideby-side comparison of aerosol properties during these periods.

Ambient particles were sampled through $3 \mathrm{~m}$ of $\mathrm{Cu}$ tubing with a $0.63 \mathrm{~cm}$ inside diameter. The inlet extended $0.5 \mathrm{~m}$ above the roof of the laboratory and was curved downward and covered with a screen to prevent rain and insects from entering. Ambient particles during GoAmazon2014/5 were not size-selected prior to collection on the filament because of low ambient concentrations. The collection process, however, is inherently dependent on particle mobility (McMurry et al., 2009). In order to determine the size-dependent collection efficiency, tests were run at the start of the campaign by generating and collecting ammonium sulfate particles in the diameter range of $8-90 \mathrm{~nm}$. The size-dependent TDCIMS sampling collection efficiencies were used to determine the volume mean diameter and estimated mass of each sample, as described in Smith et al. (2004).

\subsection{Meteorological data and complementary datasets}

To complement the TDCIMS dataset, high-resolution timeof-flight aerosol mass spectrometry (AMS; Aerodyne, Inc.) was used to characterize non-refractory compounds in $\mathrm{PM}_{1}$ at the T3 site (ARM, 2018a; de Sá et al., 2018). A seven- wavelength aethalometer was located at MAOS and measured black-carbon mass concentration (ARM, 2018b). The planetary boundary layer height (ARM, 2018c), determined using the Heffter number method (Heffter, 1980), was measured at MAOS. A scanning mobility particle sizer (ARM, 2018d) determined the number-size distributions spanning the mobility diameter range of $10-460 \mathrm{~nm}$. Wind direction, wind speed, relative humidity, temperature and rainfall were measured at AMF-1 (ARM, 2018e). Six hour back-trajectory frequency simulations were determined for the time period of interest using the NOAA HYSPLIT transport model, which uses the GDAS $1^{\circ}$ meteorology (Rolph et al., 2017; Stein et al., 2015).

\subsection{Principal component and hierarchical cluster analyses}

PCA was performed using the "princomp" function of the R statistical software package (R, 2011). A hierarchical cluster analysis was performed using Ward's averaging method in the "hclust" function in R. Ward's minimum variance method of hierarchical clustering was used, which groups species within the same cluster to minimize the total variance (Wilks, 2011). The purpose of this analysis is to identify species or groups of species that may have unique sources, trajectories or other physicochemical characteristics. Cluster analysis was done for the following TDCIMS negativeand positive-ion-mode species: $\mathrm{C}_{2} \mathrm{H}_{4} \mathrm{~N}^{-}(m / z 42), \mathrm{C}_{2} \mathrm{H}_{3} \mathrm{O}_{2}^{-}$ ( $m / z$ 59), $\mathrm{HSO}_{4}^{-}\left(m / z\right.$ 97), $\mathrm{Cl}^{-}$(isotopes $m / z 35$ and 37), $\mathrm{HC}_{2} \mathrm{O}_{4}^{-}\left(m / z\right.$ 89) $, \mathrm{NH}_{4}^{+}\left(\mathrm{H}_{2} \mathrm{O}\right)(m / z 36), \mathrm{K}^{+}(\mathrm{m} / z 39$ and $41), \mathrm{C}_{3} \mathrm{H}_{10} \mathrm{~N}^{+}(m / z 60), \mathrm{C}_{5} \mathrm{H}_{7} \mathrm{O}^{+}\left(m / z\right.$ 83), $\mathrm{C}_{5} \mathrm{H}_{8} \mathrm{NO}^{+}$ $\left(\mathrm{m} / z\right.$ 98) and $\mathrm{C}_{7} \mathrm{H}_{9} \mathrm{O}_{2}^{+}(\mathrm{m} / z$ 125). Cluster analysis was also done for the following AMS species: organic, ammonium, nitrate, sulfate and chloride. A separate cluster analysis was performed for quality assurance and demonstrated that the three clusters presented in Sect. 3.3 are statistically significant and different from one another.

\section{Results and discussion}

\subsection{Meteorological data and classification of air masses}

The 10 consecutive days that are the focus of this study can be characterized by two distinct air mass types, as determined from meteorological data and AMS-derived positive matrix factorization (PMF) factors (de Sá et al., 2018). The first period, referred to as the anthropogenic period, was from 14 March to mid-morning on 19 March, and the second period, the background period, was from mid-morning on 19 March to 24 March. The AMS-derived biomass-burning factor (BBOA), associated with levoglucosan, and the anthropogenically dominated factor (ADOA), associated with mass fragment 91 or "91fac" $\left(\mathrm{C}_{7} \mathrm{H}_{7}^{+}\right)$, were as much as 3 times larger during the anthropogenic period than background period (de Sá et al., 2018). Anthropogenic influ- 


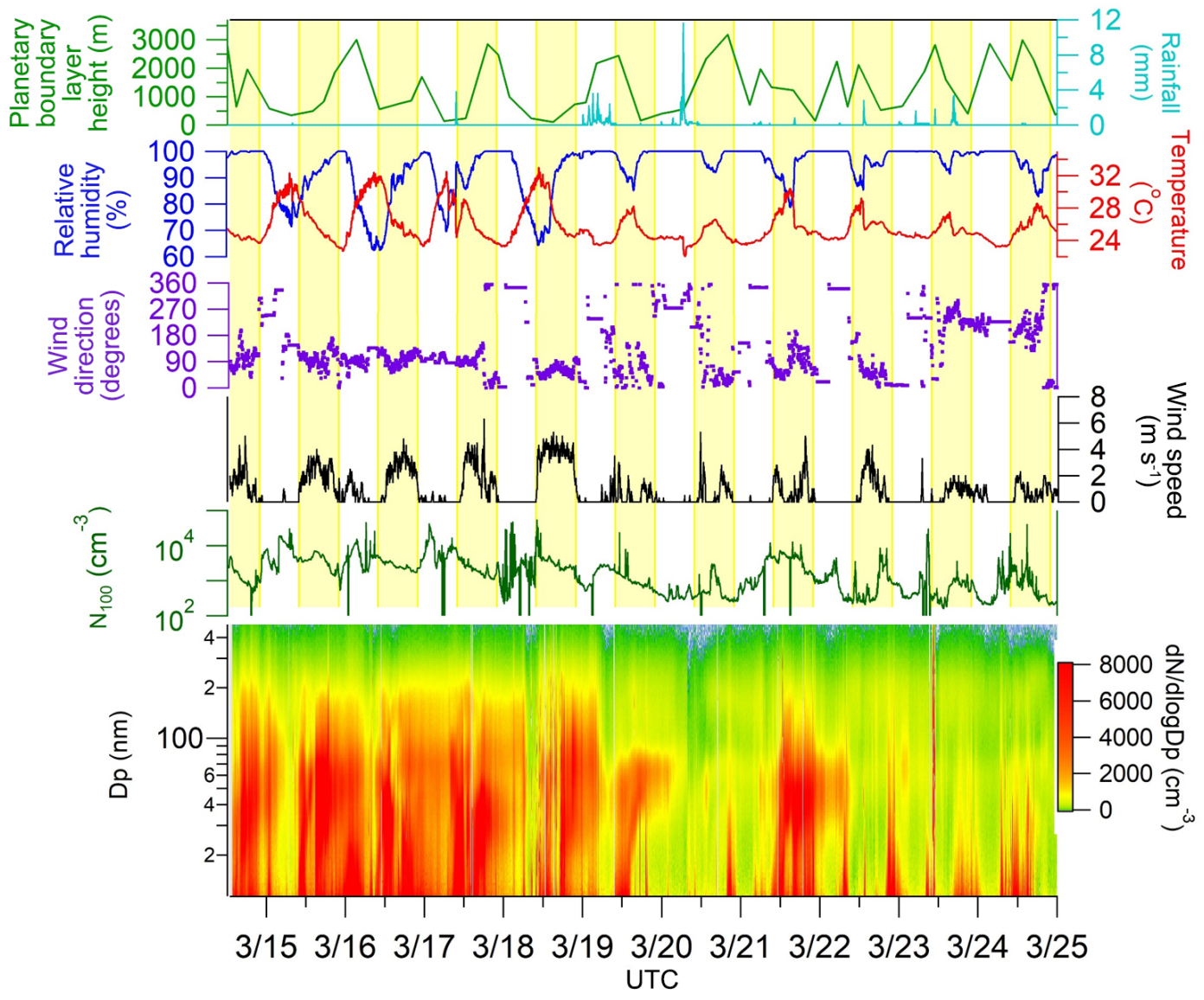

Figure 1. Meteorological data from the T3 site, showing planetary boundary layer height (green), rainfall (light blue), relative humidity (dark blue), temperature (red), wind direction (purple), wind speed (black) and total number concentration of sub-100 nm particles $\left(N_{100}\right.$; dark green). The highlighted yellow bars signify daylight hours (10:00-22:00 UTC). The particle number-size distribution contour plot shows size distribution function (molecules $\mathrm{cm}^{-3}$ ) for particle sizes between 10 and $400 \mathrm{~nm}$.

ence during this campaign, as determined using ADOA, most strongly resembled cooking emissions. Correlations between ADOA; cooking emissions; aromatics like benzene, toluene and xylene; and increased particle counts verify the link to anthropogenic influence from Manaus (de Sá et al., 2018). The particle number-size distribution, shown in Fig. 1, for the anthropogenic period saw higher number concentrations of particles over the diameter range of $10-100 \mathrm{~nm}$ $\left(N_{100}\right)$. Particle size distributions for the background period were comparable to previous measurements in the Amazon Basin, featuring a bimodal distribution with peaks at roughly 50 and $150 \mathrm{~nm}$ and peak concentrations of approximately $10^{3}$ particles $\mathrm{cm}^{-3}$ (Fig. S2; Artaxo et al., 2013; Gunthe et al., 2009; Pöhlker et al., 2016; Varanda Rizzo et al., 2018). The average total mass concentration as determined by AMS for the anthropogenic period was $2.5 \pm 0.9 \mu \mathrm{g} \mathrm{m}^{-3}$. The T3 site experienced approximately $4 \mathrm{~h}$ of rain on 19 March, ending at about noon UTC (all times are presented as UTC time, which is $4 \mathrm{~h}$ ahead of local time), and the first and only new particle formation event of this $10 \mathrm{~d}$ period was observed. After this event on 19 March, number concentrations of parti- cles were, on average, much lower than the prior period. The average total mass concentration for the background period was determined to be $1.2 \pm 0.8 \mu \mathrm{g} \mathrm{m}^{-3}$. A similar trend in total mass concentration between background and polluted conditions was observed during the Southern Oxidant and Aerosol Study (SOAS), where larger particle mass concentrations were observed during times with polluted air mass influence and, when followed by a period of rainfall, smaller mass concentrations were observed (Liu and Russell, 2017). Occasional rainfall was seen during the background period, resulting in wet deposition of aerosol particles. Additionally, a back-trajectory analysis, presented next, provides a more likely reason for these two distinct periods.

Wind direction data shown in Fig. 1, as well as NOAA HYSPLIT data shown in Fig. 2, suggest a reason for the two distinct periods. Back trajectories show that air masses during the anthropogenic period either pass through Manaus or south of Manaus prior to arrival at the T3 site. During this period, air masses most frequently passed over the main roadway that connects Manaus with Manacapuru, a neighboring city with a population of 93000 . Along this road- 
side are homes, agriculture and brick kilns, all of which contribute to local gas and particle emissions. In contrast, during the background period, air masses arrived at the T3 site most frequently from the northeast and west. Air masses that were measured at the site typically originated from densely forested regions northeast to west of Manaus. Less frequent were periods where air masses reaching the site originated from the east and were influenced by the Manaus metropolitan area. For example, during the evening of 21 March there was a period of increased number concentration, and as winds were quite stagnant at night, it is possible that a local emission source could have impacted the site during that period. Wind direction on this day corresponded with air masses arriving to the T3 site from the Manaus area.

Estimated masses of ultrafine particles sampled by TDCIMS were determined and compared for the two periods (Fig. S3). During the anthropogenic period there was no distinct diurnal pattern observed, with an average of $\sim 100 \mathrm{ng}$ per sample. This lack of a diurnal pattern in the sampled particles suggests that sources or processes that are responsible for these particles could have persisted throughout the day and night or could be from different processes that persisted both day and night. In contrast to this, the background period has a diurnal peak in estimated mass collected between 18:00 and 22:00 UTC, with sampled masses of $\sim 70 \mathrm{ng}$ per sample. The minimum sample sizes occurred in the early morning, when averages reached as low as $16 \mathrm{ng}$ per sample. Peaks in collected mass during the early afternoon could be linked to photochemically produced sources and appear to be unique to the background period. Assuming that the background contribution to the mass of particles remains constant between each time period, the average mass loading of ultrafine particles increased by a factor of 3 due to anthropogenic influence (Fig. S3).

\subsection{Ultrafine-particle chemical composition}

The five most abundant negative ions, as observed in full mass spectra (Fig. S1) taken at the start of the wet season campaign, are attributed to $\mathrm{CNO}^{-}$(cyanate, $m / z 42$ ), $\mathrm{C}_{2} \mathrm{H}_{3} \mathrm{O}_{2}^{-}$(acetate, $m / z$ 59), $\mathrm{HSO}_{4}^{-}$(bisulfate, $m / z$ 97), $\mathrm{Cl}^{-}$ (chloride, isotopes $m / z 35$ and 37) and $\mathrm{HC}_{2} \mathrm{O}_{4}^{-}$(hydrogen oxalate, $m / z$ 89). The six most abundant positive ions measured were attributed to $\mathrm{NH}_{4}^{+}\left(\mathrm{H}_{2} \mathrm{O}\right)$ (ammonium hydrate, $m / z 36$ ), $\mathrm{K}^{+}$(potassium, isotopes $m / z 39$ and 41 ), $\mathrm{C}_{3} \mathrm{H}_{10} \mathrm{~N}^{+}$ (trimethyl ammonium, $m / z 60$ ), $\mathrm{C}_{5} \mathrm{H}_{7} \mathrm{O}^{+}$(protonated 3methylfuran, $m / z$ 83), $\mathrm{C}_{5} \mathrm{H}_{8} \mathrm{NO}^{+}\left(m / z\right.$ 98) and $\mathrm{C}_{7} \mathrm{H}_{9} \mathrm{O}_{2}^{+}$ $\left(m / z\right.$ 125). We will refer to $\mathrm{C}_{5} \mathrm{H}_{8} \mathrm{NO}^{+}(\mathrm{m} / z$ 98) and $\mathrm{C}_{7} \mathrm{H}_{9} \mathrm{O}_{2}^{+}(\mathrm{m} / z$ 125) collectively as "other" in our positiveion-mode analysis, as these were minor components. The major isotopes of chloride were measured in order to understand the role chloride may have had on particle formation, with potential influence from marine aerosol and fungal spores (Pöhlker et al., 2012). Potassium (isotopes $m / z 39$ and 41) was measured during positive-ion-mode analysis to determine the potential influence of potassium-rich primary biological particles (China et al., 2016; Pöhlker et al., 2012). Additionally, potassium-rich particles have been linked to biomass burning, as potassium is found to be associated with soot carbon (Andreae, 1983; Pósfai et al., 2004). Massnormalized ion abundances, defined as ion abundance divided by the collected sample mass, for the five most abundant negative ions displayed similar diurnal patterns within each period. During the anthropogenic period, peaks in massnormalized ion abundance were observed for all measured species between 06:00 and 08:00 and 16:00 and 18:00. For the background period, there was no sharp peak observed between 16:00 and 18:00 for any of the five measured species, but there was a peak in the diurnal pattern between 06:00 and 08:00 for $m / z$ 42, $m / z 59$ and $m / z$ 89 (Fig. S4). Diurnal trends in mass-normalized ion abundances give little insight, per se, into sources of individual ions, but it is interesting to note that ion abundances are typically the lowest when the sample mass is largest. A potential reason for this is that TDCIMS is not sensitive to the specific compounds present in these ultrafine particles when the mass loading is highest. This could be true, for example, if refractory black carbon is the main constituent during the period of the highest sampled mass, as chemical ionization would be unable to detect these compounds. Since the diurnal patterns of all individual ions are similar, a comparison of ion fractions, defined as ion abundance divided by the sum of the total ion abundances measured at the time of analysis, provides a measurement of ion concentration in collected particles and shows distinct differences between the background and anthropogenic periods.

Figure $3 \mathrm{a}$ shows the trend in ion fraction for the five most abundant negative ions and four most abundant positive ions during the $10 \mathrm{~d}$ period of analysis. During the anthropogenic period, the observed bisulfate ion $(\mathrm{m} / z$ 97) fraction was larger than during the background period. Of the ions measured, bisulfate is the predominant indicator of urban influence. The bisulfate anion has been previously noted in TDCIMS analysis as a stable ion formed from the thermal desorption of particulate sulfate (Voisin et al., 2003), and it is likely that emissions from Manaus could serve as the major source for sulfate found at the $\mathrm{T} 3$ site. Thus as air masses during the anthropogenic period primarily traveled from, or to the south of, Manaus, bisulfate is expected to have a higher measured ion fraction. Additionally, inbasin emissions of various gaseous precursors like dimethyl sulfide and hydrogen sulfide could contribute to particulate sulfate of non-anthropogenic origin, as bisulfate was measured during the whole $10 \mathrm{~d}$ period of interest, even without observed direct influence from Manaus. When the bisulfate ion was the largest of the negative ions, the largest fractions of ammonium $(\mathrm{m} / \mathrm{z}, 36)$ and trimethyl ammonium $(m / z 60)$ in the positive-ion mode were observed as well. Additionally, the largest chloride $(\mathrm{m} / \mathrm{z} 35)$ signal was observed at the beginning of this period, reaching a maximum 

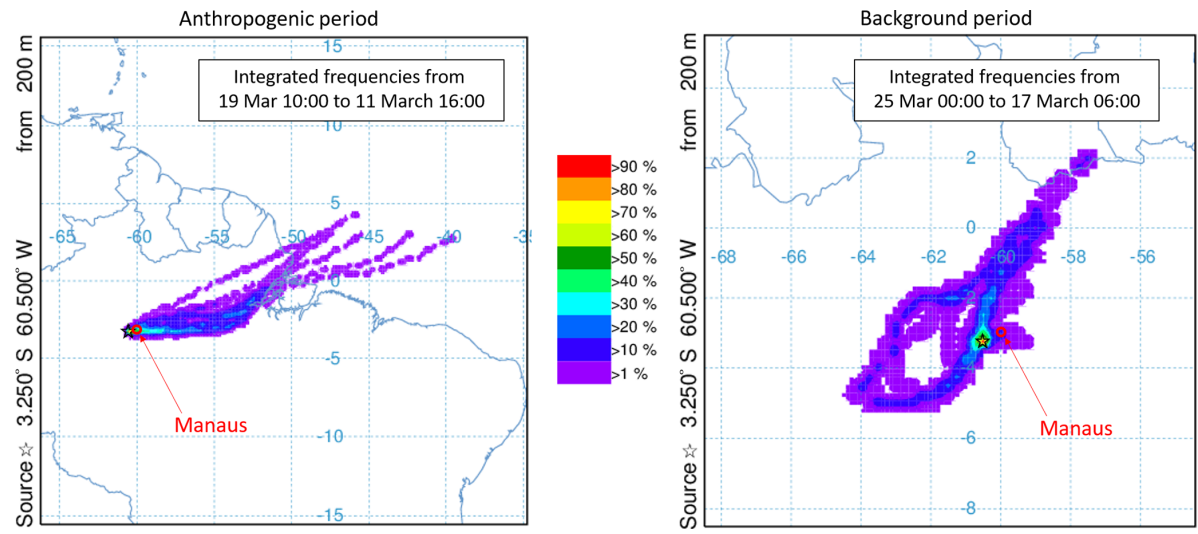

Figure 2. Back-trajectory frequencies performed using HYSPLIT, showing the different air masses that travel to the T3 site during the anthropogenic period and background period. For each period, 20 trajectories were used to determine integrated frequencies spanning the $5 \mathrm{~d}$ of each period (14-19 March for the anthropogenic and 20-25 March for the background period). Each trajectory duration was 72 h. The color scale indicates the frequency of which air masses pass over that area, with the warmer color indicating that the area is more frequently passed over.

of about $10 \%$ of the total ion fraction on 14 March. During the background period, the ion fraction of hydrogen oxalate $(\mathrm{m} / z$ 89) remained relatively constant, averaging $31 \% \pm 5 \%$ of the total ion fraction. Diurnal patterns of these ion fractions, shown in Fig. 3b, show small diurnal variations for most of the observed ions. The diurnal pattern of $m / z 42$ (cyanate) peaks between 10:00 and noon and both $m / z 59$ and $m / z 89$ show slight decreases between 10:00 and noon as well. Roughly $70 \%$ of measurements over both periods had potassium $(\mathrm{m} / \mathrm{z} 39$ and 41$)$ ion fractions less than or equal to $20 \%$ of the total positive-ion fraction, with few "potassium episodes" of higher abundance observed.

Interestingly, $m / z 42$ was the most abundant ion present in TDCIMS spectra. Due to its even mass-to-charge ratio, this ion almost certainly contains nitrogen. This ion distinguishes itself from other detected compounds by a peak in ion fraction during the morning (Fig. 3b). Prior TDCIMS measurements during the 2006 MILAGRO campaign in the Mexico City metropolitan area detected $\mathrm{m} / \mathrm{z} 42$ as a major ion fragment in sub- $20 \mathrm{~nm}$ diameter particles; that ion was identified as cyanate $\left(\mathrm{CNO}^{-}\right)$, which may be linked to isocyanic acid from biomass burning or industrial processes (Smith et al., 2008). The $m / z 42$ fragment observed in this study is not likely of anthropogenic origin, since this ion was observed during very clean periods when we expect anthropogenic emissions and biomass burning to be low. In addition, TDCIMS-measured $m / z 42$ during the dry season did not show an increase in ion intensity relative to the wet season (Smith, 2016), which one might expect if this ion were sourced to biomass burning. We hypothesize that this ion is cyanate $\left(\mathrm{CNO}^{-}\right)$, which we associate with organic nitrogen related to aerosol formation from biogenic emissions of volatile organic compounds (VOCs). Natural emissions of amino acids, water-soluble organic species and other proteinaceous biogenic materials have been measured in the gas phase, particle phase and precipitation across the globe and have been estimated to account for as much as half or more of the bulk aerosol composition over the Amazon Basin (Artaxo et al., 1988, 1990; Kourtchev et al., 2016; Mace et al., 2003; Zhang and Anastasio, 2003). While all prior field measurements in the Amazon Basin have been made on particles larger than those measured in this study, similar sources may influence ultrafine-particle composition. If true, these observations suggest that organic nitrogen compounds play a crucial role in both ultrafine-particle formation as well as growth to large particles, which make this mechanism for particle growth climatologically important in this region.

Of the measured positive-ion species, $m / z 83$, linked to 3-methylfuran or other C5 oxidized volatile organic compounds, dominated the ion fraction in ultrafine particles. Methylfuran has been observed to be produced as a thermal decomposition product of isoprene-derived SOA via AMS measurements (Allan et al., 2014), a process that would likely also occur during TDCIMS analysis. Airborne observations in the Amazon suggest that isoprene SOA can be formed in the boundary layer under certain conditions, which is confirmed by these observations (Allan et al., 2014). Since this ion is a marker of isoprene epoxydiol (IEPOX) species present in the particle phase, this confirms a role for isoprene and isoprene derivatives in the growth of ultrafine particles. Little variability in the diel pattern for $m / z 83$ is observed, similar to other particle-phase measurements of IEPOX derivatives reported for the GoAmazon2014/5 campaign by Isaacman-Vanwertz et al. (2016). In that study, weak diurnal patterns for particle-phase isoprene oxidation products were also observed even while gasphase concentrations of these species increased in the afternoon. It is important to note that this ion dominates the positive-ion fraction during both the anthropogenically influenced and background-influenced periods. Times that ex- 
(a)
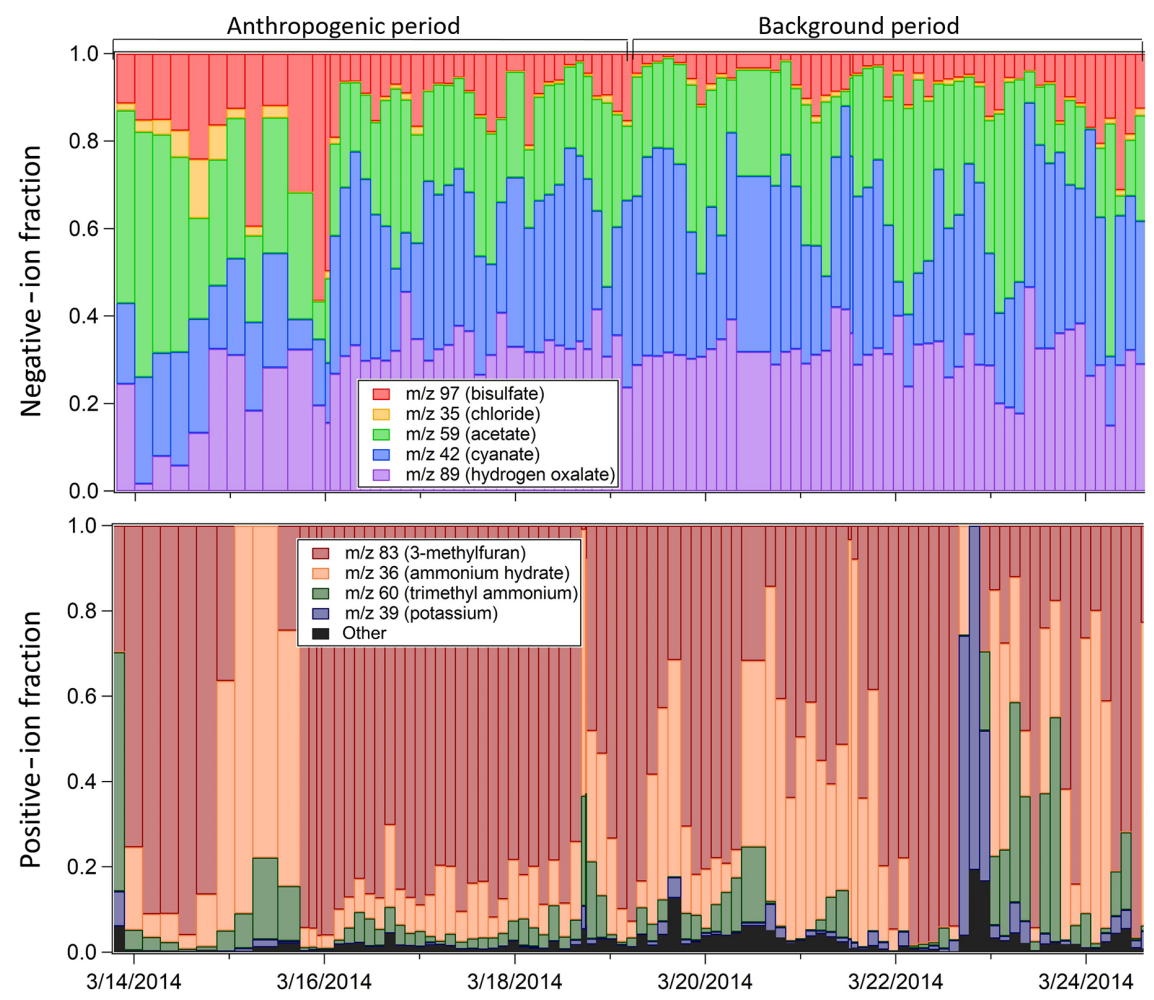

(b)
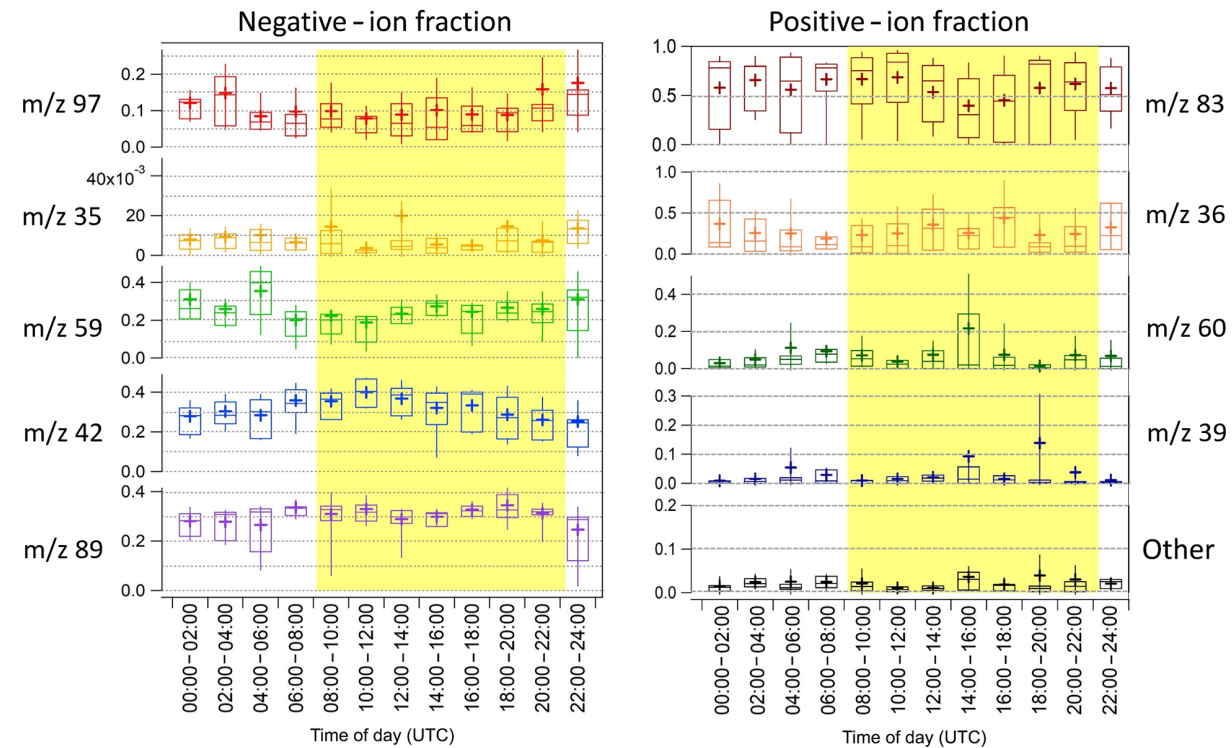

Figure 3. (a) The negative-ion fraction and positive-ion fraction shown over the $10 \mathrm{~d}$ period of interest. (b) Diel patterns of the five measured negative ions shown and of the four major positive ions; "other" refers to sum of fractions of $m / z 125$ and $m / z$ 98. The crosses are average values, the boxes show 25 th and 75 th percentiles as well as medians, and the whiskers show maximum and minimum values. Signals are averaged between the $2 \mathrm{~h}$ time blocks noted. Highlighted region denotes daylight hours.

perienced lower fractions of $m / z 83$ had increased fractions of ammonium and trimethyl ammonium, which also coincided at times with larger amounts of measured bisulfate in the negative ions. The presence of larger fractions of particulate ammonia and amines at times with less influence from isoprene-derived species could indicate that both organic salt formation and uptake of isoprene-derived products are possible mechanisms of ultrafine-particle growth. The importance of organic salt formation in growth is consistent with prior TDCIMS measurements (Smith et al., 2010), although a quantitative comparison cannot be made, since this current study focuses on sub-100 nm diameter particles, whereas the 
prior study focused on size-resolved sub- $15 \mathrm{~nm}$ ambient particles. One period of an elevated potassium ion ratio was observed at the end of the day on 22 March. To differentiate between potential sources of potassium in these ultrafine particles, whether they be of primary biological or biomassburning influence, mass concentrations of black carbon during this $10 \mathrm{~d}$ period of interest were used to examine the extent of influence of biomass burning on the presence of potassium (Fig. S5). During the anthropogenic period, with significantly elevated concentrations of black carbon, a minimal potassium fraction was measured. At times of low blackcarbon mass concentrations during the background period, like on 20 March, there was some fraction of potassium observed. During the period of the highest fraction observed on the night of 22 March, there were slightly elevated mass concentrations of black carbon. While partially elevated blackcarbon mass concentrations on 22 March may be connected to the large potassium ion fraction, at times with even more significant biomass-burning influence, there was minimal potassium. The larger fraction of potassium observed during the background period, as opposed to the anthropogenic period, may be connected to potassium-rich biological particles or the rupturing of biological spores (China et al., 2016; Pöhlker et al., 2012). Of all wet season TDCIMS measurements during GoAmazon2014/5, roughly $14 \%$ of measurements had potassium fractions greater than 0.1 (Fig. S6). Air masses on the evening of 22 March were traveling steadily from the Manaus area and coincided with about $5 \mathrm{~mm}$ of rain. High ambient concentrations of biological particles that could be sources of potassium are often associated with rainfall events (China et al., 2016). Rupturing of fungal spores, leading to the production of sub- $100 \mathrm{~nm}$ fragments, was observed to occur after long exposures (above $10 \mathrm{~h}$ ) of high relative humidity and subsequent drying, which are similar conditions to those on 22 March.

\subsection{Multivariate analysis of TDCIMS and AMS data}

PCA was performed on TDCIMS and AMS measurements to provide insights into the possible drivers for ultrafine-particle formation. Figure 4 shows the results of this analysis. In these plots, positive correlations are shown in blue, while negative correlations are shown in red. The intensity of the color and eccentricity of the ellipse are an indication of the degree of correlation. Pale-colored circles (eccentricity approximately zero) show little to no correlation, narrow ellipses with a positive slope and darker blue color illustrate strong positive correlation, and narrow ellipses with a negative slope and darker red color show strong negative correlation.

Hierarchical clustering of these measurements results in three main clusters of related particle constituents. This represents a series of clusters where the species within each cluster covary, therefore being indicative, in this work, of similar particle characteristics, processes or sources. The first cluster, labeled "Cluster 1" in Fig. 4, grouped TDCIMS-

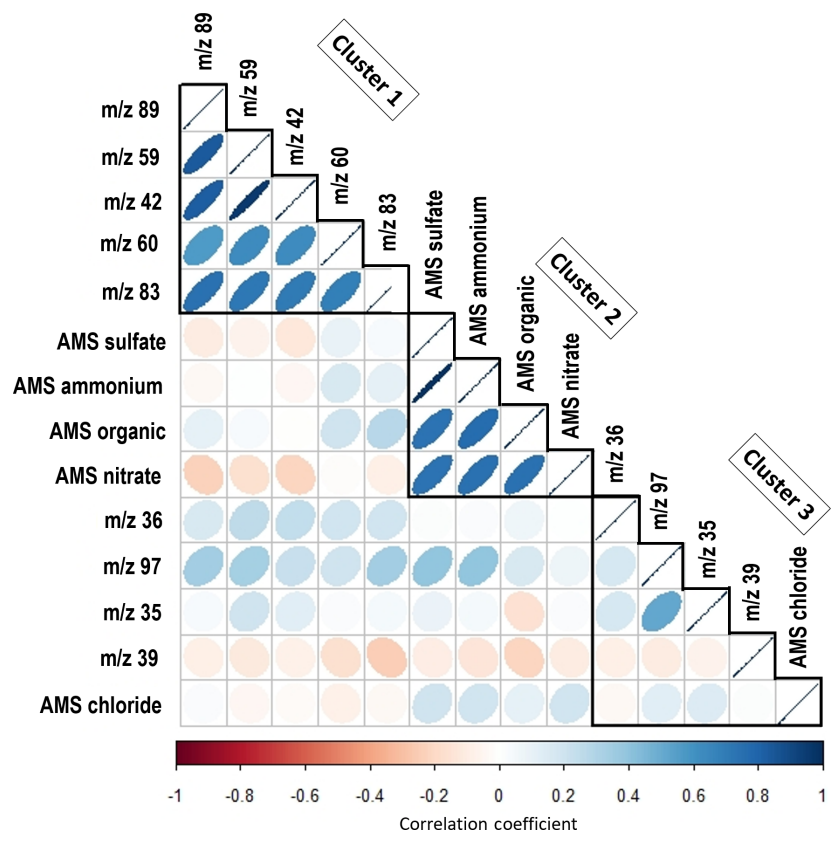

Figure 4. Principal component analysis (PCA) of TDCIMS and AMS data. Refer to text for details on the interpretation of these plots. Shown are PCA results in which species are grouped into hierarchical clusters, with clusters outlined by weighted black lines. Species are ordered by decreasing correlation to the first principal component, from the top to bottom. TDCIMS chemical assignments for fragments are $m / z 89$ (hydrogen oxalate), $m / z 59$ (acetate), $m / z 42$ (cyanate), $m / z 60$ (trimethyl ammonium), $m / z 83$ (3-methylfuran), $m / z 36$ (ammonium hydrate), $m / z, 97$ (bisulfate), $m / z 35$ (chloride) and $m / z 39$ (potassium).

derived cyanate $(m / z 42)$, acetate $(m / z 59)$, hydrogen oxalate $(m / z 89)$, trimethyl ammonium $(m / z 60)$ and $3-$ methylfuran $(m / z$ 83); the second, labeled "Cluster 2", clustered well-known covarying AMS derived constituents (U1brich et al., 2009); and the third, labeled "Cluster 3", associated AMS-derived chloride with TDCIMS-derived chloride $(m / z 35)$, bisulfate $(m / z 97)$, ammonium hydrate $(m / z 36)$ and potassium $(m / z$ 39). The hierarchical cluster approach independently grouped and separated AMS measurements from TDCIMS measurements. While both represent composition measurements of the aerosol population, the differences between the size ranges of particles measured by AMS and TDCIMS techniques would lead to the anticipated differences in clustering. Comparing mass distributions estimated by size distribution measurements, the presence of particles larger than $100 \mathrm{~nm}$ would have a more significant contribution to the measured mass concentrations by AMS. In contrast, TDCIMS only measures sub- $100 \mathrm{~nm}$ particles, representing a minor contribution to the total mass concentration. This observed separation between the clustering of AMS and TDCIMS measurements reinforces the importance of direct measurements of ultrafine particles, as opposed to bulk com- 
position, in accessing the species and mechanisms responsible for new particle formation.

With respect to PCA performed on the two datasets, Cluster 1, which includes TDCIMS fragments typically linked to organic species $(m / z 59,89$ and 83$)$ and nitrogen species discussed previously $(\mathrm{m} / \mathrm{z} 42$ and 60), explains most of the variance and has the highest correlation with the first principal component. These species' high correlation with each other indicate similar sources, most of which can be associated with BVOC emissions. A prior TDCIMS laboratory study linked the acetate ion fragment $(\mathrm{m} / z$ 59) to particulate carboxylic and dicarboxylic acids (Smith and Rathbone, 2008), which have been linked to the photochemical oxidation of both biogenic and anthropogenic compounds (Winkler et al., 2012). During the wet season in the Amazon Basin, specific dicarboxylic acids and tricarboxylic acids have been identified and proposed to have been formed from the oxidation of semi-volatile fatty acids and terpenes (Kubátová et al., 2000). Hydrogen oxalate, measured as $m / z 89$, was one of the two most abundant organic ions measured in ultrafine particles at both an urban and rural site in Helsinki, Finland (Pakkanen et al., 2000). Hydrogen oxalate was noted to have relatively constant concentrations in ultrafine particles, similar to observations seen during the $10 \mathrm{~d}$ period of analysis for this study (Fig. 3). While Helsinki and the Amazon experience different conditions and meteorology, oxalate has been observed in both environments, possibly due to the heavy BVOC influence in both locales. In the positiveion mode, 3-methylfuran, measured as $m / z$ 83, has significant correlation to background linked negative ions. These species seem to be generally linked to the oxidation of various BVOCs, whether isoprene, for 3-methylfuran, or other terpenes (Allan et al., 2014). Finally, it should be noted that the clustering of the cyanate $(\mathrm{m} / \mathrm{z} 42)$ with these organic ions provides further evidence that the source of this ion is likely clean, background chemistry rather than biomass burning. Additionally, TDCIMS-measured cyanate $(m / z 42)$ is weakly and negatively correlated to AMS-measured nitrate. During the anthropogenic period (14 March through midmorning 19 March), higher levels of inorganic nitrate were observed by AMS compared to the organic form (de Sá et al., 2018). This higher mass concentration of nitrate, attributed to inorganic nitrate as opposed to organic nitrate which would be more similar to TDCIMS-measured cyanate, should explain the slight negative correlation between the two.

Hierarchical clustering separates TDCIMS-measured ions into two clusters, with Cluster 3 including TDCIMS-derived bisulfate $(m / z 97)$, chloride $(m / z 35$ and 37$)$, ammonium hydrate $(\mathrm{m} / z$ 36) and potassium $(\mathrm{m} / \mathrm{z} 39$ and 41$)$. The separation of this cluster suggests that these constituents are linked to different sources or atmospheric processes compared to those in Cluster 1, potentially with an anthropogenic origin, as both chloride and potassium and bisulfate have been linked previously to biomass burning and anthropogenic emissions, respectively (Allen and Miguel, 1995;
Martin et al., 2010). As noted previously, the bisulfate anion is a stable ion formed from the thermal desorption of particulate sulfate (Voisin et al., 2003), and it is likely present in ultrafine particles via pollution emissions from Manaus. However, in-basin emissions of gaseous sulfate precursors, like dimethyl sulfide and hydrogen sulfide, could be linked to the measured bisulfate fraction during the entire $10 \mathrm{~d}$ period, with anthropogenic sources of sulfate increasing this background level during the anthropogenic period. In-basin chloride emissions could come from both biomass burning of common regional vegetation and long-range transport of marine ultrafine particles from the Atlantic Ocean under the influence of the trade winds (Allen and Miguel, 1995; Martin et al., 2010). The clustering of AMS chloride with TDCIMS species in Cluster 3 might suggest similar sources of chloride in both ultrafine particles and $\mathrm{PM}_{2.5}$. However, it is worth noting that AMS chloride also very weakly correlated with the other species measured by AMS. For this reason, its inclusion in this cluster indicates that AMS chloride is similar to TDCIMS-derived Cluster 3 species and also different enough so as not to cluster with the other AMS species. The production of potassium, which is potentially linked to rupturing of fungal spores and biomass burning, would have little correlation to other measured TDCIMS species, as the mechanism for the production of potassium is independent of SOA formation mechanisms. This ion is not generally associated to constant background sources, like TDCIMS species observed in Cluster 1, and may be associated with potential anthropogenic sources, like the bisulfate and chloride seen in Cluster 3. The clustering of TDCIMS ion abundances into two clusters suggests different sources and processes for these species, as there is little correlation between the species present in Cluster 1 to those present in Cluster 3.

\section{Conclusions}

The chemical composition of ultrafine particles in the Amazon Basin, as measured during the GoAmazon2014/5, has two distinct influences: sources and processes linked to anthropogenic origin and those related to more natural sources and processes. During periods of heavier anthropogenic influence, higher number concentrations of sub- $100 \mathrm{~nm}$ particles were observed (Fig. 1). HYSPLIT back trajectories during the anthropogenic period (Fig. 2) not only intersect with the Manaus metropolitan area but also with the main roadway that connects Manaus with the city of Manacapuru. Influence from anthropogenic sources, which during the study period is primarily linked to Manaus metropolitan area emissions, may continuously affect the composition of ultrafine particles observed at the T3 measurement site. Particulate sulfate, measured as the bisulfate ion, was an important and dominant contributor to the TDCIMS ion fraction during the anthropogenic period (Fig. 3) but was still measured, to a lesser extent, in the background period, suggesting an om- 
nipresent influence. The most abundant negative-ion species measured during this campaign, likely related to organic nitrogen species at $m / z$ 42, displayed a consistent morning diurnal peak and was an equally abundant constituent during both the anthropogenic and background periods. The dominance of this ion during both this study and the 2006 MILAGRO campaign in the Mexico City metropolitan area emphasizes the potential role of organic nitrogen in ultrafine aerosol particle formation and underscores the need for further research into the chemical processes and precursors that are responsible for this ion. 3-Methylfuran, measured as $m / z 83$, was the most dominant fraction observed in the positiveion mode and is likely associated with IEPOX derivatives present in ultrafine particles. The presence of these species emphasizes the importance of isoprene oxidation to particle formation in this region. The two different clusters of TDCIMS-derived ions that arise through PCA analysis, of which Cluster 1 explains most of the variance, give additional insight into the sources and processes that influence the ultrafine-particle population in this part of the Amazon Basin. As hierarchical clustering separates TDCIMS-derived organic species from TDCIMS-derived sulfate and chloride, this suggests that these species are present in the particle from different sources and/or processes. A third cluster separates AMS-measured compounds from those detected by TDCIMS, which emphasizes the unique characteristics of ultrafine particles compared to bulk aerosol particles. The lack of correlation between the two TDCIMS-derived clusters supports the observation that anthropogenic emissions and processes each have a unique role to play in ultrafineparticle formation and growth in the Amazon Basin.

Data availability. Campaign datasets for Observations and Modeling of the Green Ocean Amazon (GoAmazon) are available at https://doi.org/10.5439/1346559 (ARM, 2019).

Supplement. The supplement related to this article is available online at: https://doi.org/10.5194/acp-19-13053-2019-supplement.

Author contributions. JNS, PA, STM, OVB, RdS and JT designed the measurement campaign, and JNS, MJL, JO and SSdS carried out measurements. HSG performed data analysis, assisted by JNS and AC. HSG prepared the paper, with contributions from all coauthors.

Competing interests. The authors declare that they have no conflict of interest.

Special issue statement. This article is part of the special issue "Observations and Modeling of the Green Ocean Amazon (GoA- mazon2014/5) (ACP/AMT/GI/GMD inter-journal SI)". It is not associated with a conference.

Acknowledgements. Institutional support was provided by the Central Office of the Large Scale Biosphere-Atmosphere Experiment in Amazonia (LBA), the National Institute of Amazonian Research (INPA), and Amazonas State University (UEA) and the Fundação de Amparo à Pesquisa do Estado do Amazonas (FAPEAM). We acknowledge support from the Atmospheric Radiation Measurement (ARM) Climate Research Facility, a user facility of the United States Department of Energy, Office of Science, sponsored by the Office of Biological and Environmental Research, and support from the Atmospheric System Research (ASR; DE-SC0011122 and DESC0011115) program of that office. James N. Smith acknowledges support from a Brazilian Science Mobility Program (Programa Ciência sem Fronteiras) Special Visiting Researcher scholarship. Paulo Artaxo acknowledges funding from FAPESP - Fundação de Apoio à Pesquisa do Estado de São Paulo, grant numbers 2017/17047-0, 2013/05014-0 and 2014/50848-9.

Financial support. This research has been supported by the DOE Atmospheric System Research (grant nos. DE-SC0011122 and DESC0011115).

Review statement. This paper was edited by Lynn M. Russell and reviewed by three anonymous referees.

\section{References}

Agência de Notícias: IBGE releases population estimates for municipalities in 2017, 2017.

Allan, J. D., Morgan, W. T., Darbyshire, E., Flynn, M. J., Williams, P. I., Oram, D. E., Artaxo, P., Brito, J., Lee, J. D., and Coe, H.: Airborne observations of IEPOX-derived isoprene SOA in the Amazon during SAMBBA, Atmos. Chem. Phys., 14, 1139311407, https://doi.org/10.5194/acp-14-11393-2014, 2014.

Allen, A. G. and Miguel, A. H.: Biomass Burning in the Amazon: Characterization of the ionic component of aerosols generated from flaming and smouldering rainforest and savannah, Environ. Sci. Technol., 29, 486-493, 1995.

Alves, E. G., Jardine, K., Tota, J., Jardine, A., Yãnez-Serrano, A. M., Karl, T., Tavares, J., Nelson, B., Gu, D., Stavrakou, T., Martin, S., Artaxo, P., Manzi, A., and Guenther, A.: Seasonality of isoprenoid emissions from a primary rainforest in central Amazonia, Atmos. Chem. Phys., 16, 3903-3925, https://doi.org/10.5194/acp-16-3903-2016, 2016.

Andreae, M. O.: Soot Carbon and Excess Fine Potassium: Long-Range Transport of Combustion-Derived, available at: https://www.jstor.org/stable/pdf/1689884.pdf?refreqid= excelsior:2b4c5237f67577ae4569eb0de4192412 (last access: 23 July 2019), 1983.

Andreae, M. O.: Correlation between cloud condensation nuclei concentration and aerosol optical thickness in remote and polluted regions, Atmos. Chem. Phys., 9, 543-556, https://doi.org/10.5194/acp-9-543-2009, 2009. 
Andreae, M. O., Artaxo, P., Brandão, C., Carswell, F. E., Ciccioli, P., Costa, A. L. da, Culf, A. D., Esteves, J. L., Gash, J. H. C., Grace, J., Kabat, P., Lelieveld, J., Malhi, Y., Manzi, A. O., Meixner, F. X., Nobre, A. D., Nobre, C., Ruivo, M. D. L. P., Silva-Dias, M. A., Stefani, P., Valentini, R., von Jouanne, J., and Waterloo, M. J.: Biogeochemical cycling of carbon, water, energy, trace gases, and aerosols in Amazonia: The LBA-EUSTACH experiments, J. Geophys. Res., 107, 8066, https://doi.org/10.1029/2001JD000524, 2002.

Andreae, M. O., Rosenfeld, D., Artaxo, P., Costa, A. A., Frank, G. P., Longo, K. M., and Silva-Dias, M. A. F.: Smoking Rain Clouds over the Amazon, Science, 303, 1337-1342, 2004.

Andreae, M. O., Afchine, A., Albrecht, R., Holanda, B. A., Artaxo, P., Barbosa, H. M. J., Borrmann, S., Cecchini, M. A., Costa, A., Dollner, M., Fütterer, D., Järvinen, E., Jurkat, T., Klimach, T., Konemann, T., Knote, C., Krämer, M., Krisna, T., Machado, L. A. T., Mertes, S., Minikin, A., Pöhlker, C., Pöhlker, M. L., Pöschl, U., Rosenfeld, D., Sauer, D., Schlager, H., Schnaiter, M., Schneider, J., Schulz, C., Spanu, A., Sperling, V. B., Voigt, C., Walser, A., Wang, J., Weinzierl, B., Wendisch, M., and Ziereis, H.: Aerosol characteristics and particle production in the upper troposphere over the Amazon Basin, Atmos. Chem. Phys., 18, 921-961, https://doi.org/10.5194/acp-18-921-2018, 2018.

ARM: Aerosol Mass Spectrometer Particle Composition measurements during GoAmazon2014/5, data portal, available at: https://iop.archive.arm.gov/arm-iop/2014/mao/goamazon/T3/ alexander-ams/ (last access: 27 June 2018), 2018a.

ARM: Aethalometer measurements during GoAmazon2014/5, data portal, available at: https://iop.archive.arm.gov/arm-iop/2014/ mao/goamazon/T3/sedlacek-aeth (last access: 30 June 2019), 2018b.

ARM: Atmospheric Radiation Measurement (ARM) Climate Research Facility. 2013, updated hourly, Planetary Boundary Layer Height (PBLHTSONDE1MCFARL), 2014-03-10 to 2014-0310, ARM Mobile Facility (MAO) Manacapuru, Amazonas, Brazil; AMF1 (M1), Compiled by C. Sivar, 2018c.

ARM: Atmospheric Radiation Measurement ARM Climate Research Facility, 2014, updated hourly, Scanning mobility particle sizer (AOSSMPS). 2014-03-13 to 2014-03-24, ARM Mobile Facility (MAO) Manacapuru, Amazonas, 2018d.

ARM: Wind speed, wind direction, temperature, precipitation and relative humidity during GoAmazon2014/5, data portal, available at: https://iop.archive.arm.gov/arm-iop/2014/mao/ goamazon/T3/springston-met/ (last access: 27 June 2018), 2018e.

ARM: Campaign Datasets for Observations and Modeling of the Green Ocean Amazon (GoAmazon), https://doi.org/10.5439/1346559, last access: 10 October 2019.

Artaxo, P., Storms, H., Bruynseels, F., Grieken, R. V., and Maenhaut, W.: Composition and Sources of Aerosols From the Amazon Basin, J. Geophys. Res., 93, 1605-1615, 1988.

Artaxo, P., Maenhaut, W., Storms, H., and Van Grieken, R.: Aerosol characteristics and sources for the Amazon Basin during the wet season, J. Geophys. Res., 95, 16971, https://doi.org/10.1029/JD095iD10p16971, 1990.

Artaxo, P., Rizzo, L. V., Brito, J. F., Barbosa, H. M. J., Arana, A., Sena, E. T., Cirino, G. G., Bastos, W., Martin, S. T., and Andreae, M. O.: Atmospheric aerosols in Amazonia and land use change: from natural biogenic to biomass burning conditions, Faraday Discuss., 165, 203, https://doi.org/10.1039/c3fd00052d, 2013.

Bzdek, B. R., Zordan, C. A., Luther III, G. W., Johnston, M. V., and Luther, G. W.: Nanoparticle Chemical Composition During New Particle Formation, Aerosol Sci. Technol., 458, https://doi.org/10.1080/02786826.2011.580392, 2011.

Carlton, A. G., Pye, H. O. T., Baker, K. R., and Hennigan, C. J.: Additional Benefits of Federal Air-Quality Rules: Model Estimates of Controllable Biogenic Secondary Organic Aerosol, Environ. Sci. Technol., 52, 9254-9265, https://doi.org/10.1021/acs.est.8b01869, 2018.

China, S., Wang, B., Weis, J., Rizzo, L., Brito, J., Cirino, G. G., Kovarik, L., Artaxo, P., Gilles, M. K., and Laskin, A.: Rupturing of Biological Spores As a Source of Secondary Particles in Amazonia, Environ. Sci. Technol, 50, 12179-12186, https://doi.org/10.1021/acs.est.6b02896, 2016.

de Sá, S. S., Palm, B. B., Campuzano-Jost, P., Day, D. A., Newburn, M. K., Hu, W., Isaacman-VanWertz, G., Yee, L. D., Thalman, R., Brito, J., Carbone, S., Artaxo, P., Goldstein, A. H., Manzi, A. O., Souza, R. A. F., Mei, F., Shilling, J. E., Springston, S. R., Wang, J., Surratt, J. D., Alexander, M. L., Jimenez, J. L., and Martin, S. T.: Influence of urban pollution on the production of organic particulate matter from isoprene epoxydiols in central Amazonia, Atmos. Chem. Phys., 17, 6611-6629, https://doi.org/10.5194/acp-17-6611-2017, 2017.

de Sá, S. S., Palm, B. B., Campuzano-Jost, P., Day, D. A., Hu, W., Isaacman-VanWertz, G., Yee, L. D., Brito, J., Carbone, S., Ribeiro, I. O., Cirino, G. G., Liu, Y., Thalman, R., Sedlacek, A., Funk, A., Schumacher, C., Shilling, J. E., Schneider, J., Artaxo, P., Goldstein, A. H., Souza, R. A. F., Wang, J., McKinney, K. A., Barbosa, H., Alexander, M. L., Jimenez, J. L., and Martin, S. T.: Urban influence on the concentration and composition of submicron particulate matter in central Amazonia, Atmos. Chem. Phys., 18, 12185-12206, https://doi.org/10.5194/acp-18-121852018, 2018.

de Sá, S. S., Rizzo, L. V., Palm, B. B., Campuzano-Jost, P., Day, D. A., Yee, L. D., Wernis, R., Isaacman-VanWertz, G., Brito, J., Carbone, S., Liu, Y. J., Sedlacek, A., Springston, S., Goldstein, A. H., Barbosa, H. M. J., Alexander, M. L., Artaxo, P., Jimenez, J. L., and Martin, S. T.: Contributions of biomassburning, urban, and biogenic emissions to the concentrations and light-absorbing properties of particulate matter in central Amazonia during the dry season, Atmos. Chem. Phys., 19, 79738001, https://doi.org/10.5194/acp-19-7973-2019, 2019.

Fan, J., Rosenfeld, D., Zhang, Y., Giangrande, S. E., Li, Z., Machado, L. A. T., Martin, S. T., Yang, Y., Wang, J., Artaxo, P., Barbosa, H. M. J., Braga, R. C., Comstock, J. M., Feng, Z., Gao, W., Gomes, H. B., Mei, F., Pöhlker, C., Pöhlker, M. L., Pöschl, U., and De Souza, R. A. F.: Substantial convection and precipitation enhancements by ultrafine aerosol particles, Science, 359, 411-418, https://doi.org/10.1126/science.aan8461, 2018.

Graham, B., Guyon, P., Maenhaut, W., Taylor, P. E., Ebert, M., Matthias-Maser, S., Mayol-Bracero, O. L., Godoi, R. H. M., Artaxo, P., Meixner, F. X., Moura, M. A. L., Rocha, C. H. E. D., Grieken, R. Van, Glovsky, M. M., Flagan, R. C., and Andreae, M. O.: Composition and diurnal variability of the natural Amazonian aerosol, J. Geophys. Res.-Atmos., 108, n/a-n/a, https://doi.org/10.1029/2003JD004049, 2003. 
Gunthe, S. S., King, S. M., Rose, D., Chen, Q., Roldin, P., Farmer, D. K., Jimenez, J. L., Artaxo, P., Andreae, M. O., Martin, S. T., and Pöschl, U.: Cloud condensation nuclei in pristine tropical rainforest air of Amazonia: size-resolved measurements and modeling of atmospheric aerosol composition and CCN activity, Atmos. Chem. Phys., 9, 7551-7575, https://doi.org/10.5194/acp9-7551-2009, 2009.

Heffter, J. L.: Transport Layer Depth Calculations, in Second Joint Conference on Applications of Air Pollution Meteorology, New Orleans, Louisiana, 1980.

Hofmann, D. J.: Climate Forcing by Anthropogenic Aerosols, Science, 255, 423-430, https://doi.org/10.1126/science.255.5043.423, 2015.

Intergovernmental Panel on Climate Change: Climate Change 2013: The Physical Science Basis, Contribution of Working Group 1 to the Fifths Assessment Report of the Intergovernmental Panel on Climate Change, 2013.

Isaacman-Vanwertz, G., Yee, L. D., Kreisberg, N. M., Wernis, R., Moss, J. A., Hering, S. V, De Saì, S. S., Martin, S. T., Alexander, M. L., Palm, B. B., Hu, W., Campuzano-Jost, P., Day, D. A., Jimenez, J. L., Riva, M., Surratt, J. D., Viegas, J., Manzi, A., Edgerton, E., Baumann, K., Souza, R., Artaxo, P. and Goldstein, A. H.: Ambient Gas-Particle Partitioning of Tracers for Biogenic Oxidation, Environ. Sci. Technol., 50, 9952-9962, https://doi.org/10.1021/acs.est.6b01674, 2016.

Jardine, A. B., Jardine, K. J., Fuentes, J. D., Martin, S. T., Martins, G., Durgante, F., Carneiro, V., Higuchi, N., Manzi, A. O., and Chambers, J. Q.: Highly reactive light-dependent monoterpenes in the Amazon, Geophys. Res. Lett., 42, 1576-1583, https://doi.org/10.1002/2014GL062573, 2015.

Jardine, K., Yañez Serrano, A., Arneth, A., Abrell, L., Jardine, A., Van Haren, J., Artaxo, P., Rizzo, L. V., Ishida, F. Y., Karl, T., Kesselmeier, J., Saleska, S., and Huxman, T.: Within-canopy sesquiterpene ozonolysis in Amazonia, J. Geophys. Res.-Atmos., 116, 1-10, https://doi.org/10.1029/2011JD016243, 2011.

Jimenez, J. L., Canagaratna, M. R., Donahue, N. M., Prevot, A. S. H., Zhang, Q., Kroll, J. H., DeCarlo, P. F., Allan, J. D., Coe, H., Ng, N. L., Aiken, A. C., Docherty, K. S., Ulbrich, I. M., Grieshop, A. P., Robinson, A. L., Duplissy, J., Smith, J. D., Wilson, K. R., Lanz, V. A., Hueglin, C., Sun, Y. L., Tian, J., Laaksonen, A., Raatikainen, T., Rautiainen, J., Vaattovaara, P., Ehn, M., Kulmala, M., Tomlinson, J. M., Collins, D. R., Cubison, M. J., Dunlea, J., Huffman, J. A., Onasch, T. B., Alfarra, M. R., Williams, P. I., Bower, K., Kondo, Y., Schneider, J., Drewnick, F., Borrmann, S., Weimer, S., Demerjian, K., Salcedo, D., Cottrell, L., Griffin, R., Takami, A., Miyoshi, T., Hatakeyama, S., S., A., Sun, J. Y., Zhang, Y. M., Dzepina, K., Kimmel, J. R., Sueper, D., Jayne, J. T., Herndon, S. C., Trimborn, A. M., Williams, L. R., Wood, C., E., Middlebrook, A. M., Kolb, C. E., Baltensperger, U., and Worsnop, D. R.: Evolution of organic aerosols in the atmosphere, Science, 326, 1525-1529, 2009.

Kourtchev, I., Godoi, R. H. M., Connors, S., Levine, J. G., Archibald, A. T., Godoi, A. F. L., Paralovo, S. L., Barbosa, C. G. G., Souza, R. A. F., Manzi, A. O., Seco, R., Sjostedt, S., Park, J.H., Guenther, A., Kim, S., Smith, J., Martin, S. T., and Kalberer, M.: Molecular composition of organic aerosols in central Amazonia: an ultra-high-resolution mass spectrometry study, Atmos. Chem. Phys., 16, 11899-11913, https://doi.org/10.5194/acp-1611899-2016, 2016.
Kubátová, A., Vermeylen, R., Claeys, M., Cafmeyer, J., Maenhaut, W., Roberts, G., and Artaxo, P.: Carbonaceous aerosol characterization in the Amazon basin, Brazil: Novel dicarboxylic acids and related compounds, Atmos. Environ., 34, 5037-5051, 2000.

Lawler, M. J., Rissanen, M. P., Ehn, M., Mauldin, R. L., Sarnela, N., Sipilä, M., and Smith, J. N.: Evidence for Diverse Biogeochemical Drivers of Boreal Forest New Particle Formation, Geophys. Res. Lett., 45, 2038-2046, https://doi.org/10.1002/2017GL076394, 2018.

Liu, J. and Russell, L. M.: Observational evidence for pollutioninfluenced selectiveuptake contributing to biogenic secondary organicaerosols in the southeastern U.S., Geophys. Res. Lett., 44, 8056-8064, 2017.

Mace, K. A., Artaxo, P., and Duce, R. A.: Water-soluble organic nitrogen in Amazon Basin aerosols during the dry (biomass burning) and wet seasons, J. Geophys. Res., 108, 4512, https://doi.org/10.1029/2003JD003557, 2003.

Martin, S. T., Andreae, M. O., Artaxo, P., Baumgardner, D., Chen, Q., Goldstein, A. H., Guenther, A., Heald, C. L., MayolBracero, O. L., McMurry, P. H., Pauliquevis, T., Pöschl, U., Prather, K. A., Roberts, G. C., Saleska, S. R., Silva Dias, M. A., Spracklen, D. V., Swietlicki, E., and Trebs, I.: Sources and properties of Amazonian aerosol particles, Rev. Geophys., 48, 1-42, https://doi.org/10.1029/2008RG000280, 2010.

Martin, S. T., Artaxo, P., Machado, L. A. T., Manzi, A. O., Souza, R. A. F., Schumacher, C., Wang, J., Andreae, M. O., Barbosa, H. M. J., Fan, J., Fisch, G., Goldstein, A. H., Guenther, A., Jimenez, J. L., Pöschl, U., Silva Dias, M. A., Smith, J. N., and Wendisch, M.: Introduction: Observations and Modeling of the Green Ocean Amazon (GoAmazon2014/5), Atmos. Chem. Phys., 16, 47854797, https://doi.org/10.5194/acp-16-4785-2016, 2016.

McMurry, P. H., Ghimire, A., Ahn, H.-K., Sakurai, H., Moore, K., Stolzenburg, M., and Smith, J. N.: Sampling Nanoparticles for Chemical Analysis by Low Resolution Electrical Mobility Classification, Environ. Sci. Technol., 43, 4653-4658, https://doi.org/10.1021/es8029335, 2009.

Pakkanen, T. A., Korhonen, C. H., Hillamo, R. E., Aurela, M., Aarnio, P., Koskentalo, T., and Maenhaut, W.: Ultrafine particles $\left(\mathrm{PM}_{0.1}\right)$ in the Helsinki area, J. Aerosol Sci., 31, 522-523, https://doi.org/10.1016/S0021-8502(00)90535-4, 2000.

Pöhlker, C., Wiedemann, T., Sinha, B., Shiraiwa, M., Gunthe, S., Smith, M., Su, H., Artaxo, P., Chen, Q., Cheng, Y., Elbert, W., Gilles, M., Kilcoyn, A., Moffet, R., Weigand, M., Martin, S., Pöschl, U., and Andreae, M.: Biogenic Potassium Salt Particles as Seeds for Secondary Organic Aerosol in the Amazon, Science, 337, 1075-1078, 2012.

Pöhlker, M. L., Pöhlker, C., Ditas, F., Klimach, T., Hrabe de Angelis, I., Araújo, A., Brito, J., Carbone, S., Cheng, Y., Chi, X., Ditz, R., Gunthe, S. S., Kesselmeier, J., Könemann, T., Lavrič, J. V., Martin, S. T., Mikhailov, E., Moran-Zuloaga, D., Rose, D., Saturno, J., Su, H., Thalman, R., Walter, D., Wang, J., Wolff, S., Barbosa, H. M. J., Artaxo, P., Andreae, M. O., and Pöschl, U.: Longterm observations of cloud condensation nuclei in the Amazon rain forest - Part 1: Aerosol size distribution, hygroscopicity, and new model parametrizations for CCN prediction, Atmos. Chem. Phys., 16, 15709-15740, https://doi.org/10.5194/acp-16-157092016, 2016.

Pósfai, M., Gelencsér, A., Simonics, R., Arató, K., Li, J., and Hobbs, P. V: Atmospheric tar balls: Particles from biomass 
and biofuel burning, J. Geophys. Res.-Atmos., 109, D06213, https://doi.org/10.1029/2003JD004169, 2004.

R: A Language and Environment for Statistical Computing, R Found. Stat. Comput., 1, 409, https://doi.org/10.1007/978-3-54074686-7, 2011.

Rcia, M., Yamasoe, A., Artaxo, P., Miguel, A. H., and Allen, A. G.: Chemical composition of aerosol particles from direct emissions of vegetation in the Amazon Basin: water-soluble species and trace elements, Atmos. Environ., 34, 1641-1653, 2000.

Riipinen, I., Yli-Juuti, T., Pierce, J. R., Petäjä, T., Worsnop, D. R., Kulmala, M., and Donahue, N. M.: The contribution of organics to atmospheric nanoparticle growth, Nat. Publ. Gr., 5, 453-458, https://doi.org/10.1038/NGEO1499, 2012.

Rolph, G., Stein, A., and Stunder, B.: Real-time Environmental Applications and Display sYstem: READY, Environ. Model. Softw., 95, 210-228, https://doi.org/10.1016/j.envsoft.2017.06.025, 2017.

Shrivastava, M., Cappa, C. D., Fan, J., Goldstein, A. H., Guenther, A. B., Jimenez, J. L., Kuang, C., Laskin, A., Martin, S. T., Ng, N. L., Petaja, T., Pierce, J. R., Rasch, P. J., Roldin, P., Seinfeld, J. H., Shilling, J., Smith, J. N., Thornton, J. A., Volkamer, R., Wang, J., Worsnop, D. R., Zaveri, R. A., Zelenyuk, A., and Zhang, Q.: Recent advances in understanding secondary organic aerosol: Implications for global climate forcing, Rev. Geophys., 55, 509559, https://doi.org/10.1002/2016RG000540, 2017.

Smith, J. N.: Thermal Desorption Chemical Ionization Mass Spectrometry during GoAmazon2014/5, data portal, available at: https://iop.archive.arm.gov/arm-iop/2014/mao/goamazon/ T3/smith-tdcims (last access: 10 October 2019), 2016.

Smith, J. N. and Rathbone, G. J.: Carboxylic acid characterization in nanoparticles by thermal desorption chemical ionization mass spectrometry, Int. J. Mass Spectrom., 274, 8-13, 2008.

Smith, J. N., Moore, K. F., McMurry, P. H., and Eisele, F. L.: Atmospheric Measurements of Sub-20 nm Diameter Particle Chemical Composition by Thermal Desorption Chemical Ionization Mass Spectrometry, Aerosol Sci. Technol., 38, 100-110, https://doi.org/10.1080/02786820490249036, 2004.

Smith, J. N., Dunn, M. J., VanReken, T. M., Iida, K., Stolzenburg, M. R., McMurry, P. H., and Huey, L. G.: Chemical composition of atmospheric nanoparticles formed from nucleation in Tecamac, Mexico: Evidence for an important role for organic species in nanoparticle growth, Geophys. Res. Lett., 35, 2-6, https://doi.org/10.1029/2007GL032523, 2008.

Smith, J. N., Barsanti, K. C., Friedli, H. R., Ehn, M., Kulmala, M., Collins, D. R., Scheckman, J. H., Williams, B. J., and McMurry, P. H.: Observations of aminium salts in atmospheric nanoparticles and possible climatic implications, P. Natl. Acad. Sci. USA, 107, 6634-6639, https://doi.org/10.1073/pnas.0912127107, 2010.

Stein, A. F., Draxler, R. R., Rolph, G. D., Stunder, B. J. B., Cohen, M. D., and Ngan, F.: Noaa's hysplit atmospheric transport and dispersion modeling system, B. Am. Meteorol. Soc., 96, 20592077, https://doi.org/10.1175/BAMS-D-14-00110.1, 2015.

Ulbrich, I. M., Canagaratna, M. R., Zhang, Q., Worsnop, D. R., and Jimenez, J. L.: Interpretation of organic components from Positive Matrix Factorization of aerosol mass spectrometric data, Atmos. Chem. Phys., 9, 2891-2918, https://doi.org/10.5194/acp-92891-2009, 2009.
Varanda Rizzo, L., Roldin, P., Brito, J., Backman, J., Swietlicki, E., Krejci, R., Tunved, P., Petäjä, T., Kulmala, M., and Artaxo, P.: Multi-year statistical and modeling analysis of submicrometer aerosol number size distributions at a rain forest site in Amazonia, Atmos. Chem. Phys., 18, 10255-10274, https://doi.org/10.5194/acp-18-10255-2018, 2018.

Voisin, D., Smith, J. N., Sakurai, H., Mcmurry, P. H., and Eisele, F. L.: Thermal Desorption Chemical Ionization Mass Spectrometer for Ultrafine Particle Chemical Composition, Aerosol Sci. Technol., 37, 471-475, https://doi.org/10.5439/1562451, 2003.

Wang, J., Krejci, R., Giangrande, S., Kuang, C., Barbosa, H. M. J., Brito, J., Carbone, S., Chi, X., Comstock, J., Ditas, F., Lavric, J., Manninen, H. E., Mei, F., Moran-Zuloaga, D., Pöhlker, C., Pöhlker, M. L., Saturno, J., Schmid, B., Souza, R. A. F., Springston, S. R., Tomlinson, J. M., Toto, T., Walter, D., Wimmer, D., Smith, J. N., Kulmala, M., Machado, L. A. T., Artaxo, P., Andreae, M. O., Petäjä, T., and Martin, S. T.: Amazon boundary layer aerosol concentration sustained by vertical transport during rainfall, Nat. Publ. Gr., 539, https://doi.org/10.1038/nature19819, 2016.

Wilks, D. S.: Statistical methods in the atmospheric sciences, Elsevier/Academic Press, 2011.

Winkler, P. M., Ortega, J., Karl, T., Cappellin, L., Friedli, H. R., Barsanti, K., McMurry, P. H., and Smith, J. N.: Identification of the biogenic compounds responsible for sizedependent nanoparticle growth, Geophys. Res. Lett., 39, 1-6, https://doi.org/10.1029/2012GL053253, 2012.

Yáñez-Serrano, A. M., Nölscher, A. C., Williams, J., Wolff, S., Alves, E., Martins, G. A., Bourtsoukidis, E., Brito, J., Jardine, K., Artaxo, P., and Kesselmeier, J.: Diel and seasonal changes of biogenic volatile organic compounds within and above an Amazonian rainforest, Atmos. Chem. Phys., 15, 3359-3378, https://doi.org/10.5194/acp-15-3359-2015, 2015.

Yee, L. D., Isaacman-VanWertz, G., Wernis, R. A., Meng, M., Rivera, V., Kreisberg, N. M., Hering, S. V., Bering, M. S., Glasius, M., Upshur, M. A., Gray Bé, A., Thomson, R. J., Geiger, F. M., Offenberg, J. H., Lewandowski, M., Kourtchev, I., Kalberer, M., de Sá, S., Martin, S. T., Alexander, M. L., Palm, B. B., Hu, W., Campuzano-Jost, P., Day, D. A., Jimenez, J. L., Liu, Y., McKinney, K. A., Artaxo, P., Viegas, J., Manzi, A., Oliveira, M. B., de Souza, R., Machado, L. A. T., Longo, K., and Goldstein, A. H.: Observations of sesquiterpenes and their oxidation products in central Amazonia during the wet and dry seasons, Atmos. Chem. Phys., 18, 10433-10457, https://doi.org/10.5194/acp-18-104332018, 2018.

Zhang, Q. and Anastasio, C.: Free and combined amino compounds in atmospheric fine particles $\left(\mathrm{PM}_{2.5}\right)$ and fog waters from Northern California, Atmos. Environ., 37, 2247-2258, https://doi.org/10.1016/S1352-2310(03)00127-4, 2003.

Zhou, J., Swietlicki, E., Hansson, H. C., and Artaxo, P.: Submicrometer aerosol particle size distribution and hygroscopic growth measured in the Amazon rain forest during the wet season, J. Geophys. Res.-Atmos., 107, 22-1-22-10 https://doi.org/10.1029/2000JD000203, 2002. 